\title{
Lonchaeidae (Diptera) species and their host plants in the Cerrado biome in the state of Piauí, Brazil
}

\author{
Espécies de Lonchaeidae (Diptera) e seus \\ hospedeiros no bioma Cerrado no estado do Piauí, Brasil
}

\section{Francieli Nunes da Silva Vieira' (D), Ester Marques de Sousa² (D), Léo Rodrigo Ferreira Louzeiro ${ }^{2 *}$ (D), Sara Braga e Silva ${ }^{2}$}

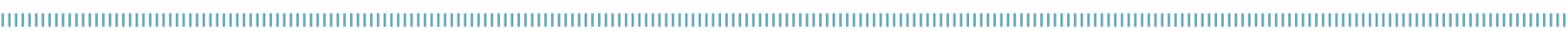

\begin{abstract}
Some species of Lonchaeidae (Diptera) are considered frugivorous and polyphagous pests, and are widely distributed in Neotropical regions. The relationship between a fly and its host plant is important for studies on behavior and distribution of frugivorous flies. The objective of this work was to identify the Lonchaeidae fly species and their host plants in the Cerrado biome, specifically in the state of Piauí, Brazil. Eighty-one adults (33 $q$ and $48 \delta^{\pi}$ ) from the genus Neosilba McAlpine (Lonchaeidae), represented by the species Neosilba inesperata Strikis \& Prado, Neosilba pendula Bezzi, and Neosilba zadolicha McAlpine, were collected from fruit samples. Oranges [Citrus sinensis (L.) Osbeck] and guava (Psidium guajava L.) had the highest frequencies of infestation. A Neosilba species was considered a primary invader in orange. These results are the first ones reported of Lonchaeidae species and their host plants in the state of Piauí.
\end{abstract}

KEYWORDS: Neosilba; host fruits; Citrus sinensis; primary invader.
RESUMO: Algumas espécies de Lonchaeidae (Diptera) são consideradas pragas frugívoras e polífagas, com ampla distribuição geográfica em regióes neotropicais. A relação mosca/planta hospedeira é de grande valor para estudos de comportamento e distribuição de moscas frugívoras. O objetivo deste trabalho foi identificar as espécies de Lonchaeidae e suas plantas hospedeiras no bioma Cerrado, especificamente no estado do Piauí, Brasil. Oitenta e um adultos (33 q e 48 ठ) do gênero Neosilba McAlpine (Lonchaeidae), pertencentes às espécies Neosilba inesperata Strikis \& Prado, Neosilba pendula Bezzi e Neosilba zadolicha McAlpine, foram coletados de amostras de frutas, sendo a laranja [Citrus sinensis (L.) Osbeck] e a goiaba (Psidium guajava L.) as de maiores frequências de infestação. Uma espécie de Neosilba foi considerada um invasor primário em laranjas. Esses resultados são os primeiros relatos de espécies de Lonchaeidae e suas plantas hospedeiras no estado do Piauí.

PALAVRAS-ChAVE: Neosilba; frutos hospedeiros; Citrus sinensis; invasor primário. 
Family Lonchaeidae (Diptera) is composed of a group of black flies with metallic glows. They are between 3 and $6 \mathrm{~mm}$ long and are mainly found in the Neotropical region. Lonchaeidae develop in flowers, fruits, seeds, cacti and decomposing organic matter during immature stages (MCALPINE, 1961). The genera Dasiops Rondani has 128 species, and Neosilba McAlpine has 40 species (EDIT, 2013). Dasiops and Neosilba are the most economically important genera, including frugivorous and polyphagous species (STRIKIS et al., 2011).

The first studies on Lonchaeidae described its species as secondary pests due to their attack on already infested fruits by Tephritidae (STRIKIS; PRADO, 2005). However, new studies characterize some of these species as primary, polyphagous, and economically important pests for fruit crops (UCHÔA-FERNANDES et al., 2002; RAGA et al., 2015; RIQUELME et al., 2015).

Studies in Brazil report the use of McPhail traps with food bait to evaluate the presence of Lonchaeidae in the states of São Paulo (RAGA et al., 2006), Mato Grosso do Sul (UCHÔA-FERNANDES et al., 2003) and Tocantins (BOMFIM et al., 2007). In addition, there are reports of infestations in barbados cherry (Malpighia emarginata Sessé \& Moc. Ex DC), in Rio Grande do Norte (ARAÚJO; ZUCCHI, 2002); guava (Psidium guajava L.), loquat [Eriobotrya japonica (Thunb.) Lindl.], peach [Prunuspersica (L.) Batsch] (SOUZA FILHO et al., 2009), and coffee (Coffea arabica L.), in São Paulo (RAGA et al., 1996); orange [Citrus sinensis (L.) Osbeck], in Rio de Janeiro (SOUZA et al., 2008); tangerine (Citrus reticulata Blanco), in Paraíba (LOPES et al., 2007); and in several fruits collected in Acre, Amapá, Pará, Rondônia, and Roraima (SILVA et al., 2011).

Some species of Lonchaeidae are frugivorous and polyphagous pests and are widely distributed throughout Brazil. Information on the relationship between flies and their host plants is important to study spatial distribution of frugivorous flies and their use of host plants. These studies allow us to know the behavior of these insect pests in Brazil's atypical environments, such as the Cerrado biome, in the state of Piauí, and the Lonchaeidae's potential to be a primary invader of fruits in these environments.

Therefore, our goals were to identify the Lonchaeidae fly species and their host plants in the state of Piauí, located in the Cerrado biome, and to assess if these insects are primary invaders of fruits in this region.

Fruit samples were collected in the municipality of Corrente based on the availability in rural and urban areas and were separated by species. Then, they were counted, weighed, and placed in plastic trays $(36 \times 27 \times 12 \mathrm{~cm})$ containing sterilized sand. Thereafter, they were labeled and covered with cotton cloth fixed with rubber band. The pupae were sieved and separated every seven days and were placed in 500-mL-glass pots containing moistened sand, which were sealed with cotton cloth fixed with rubber band. The adults were killed by freezing at $-11^{\circ} \mathrm{C}$, and then transferred to labeled vials with alcohol $70 \%$. The infestation index and infestation frequency were evaluated to establish the status of the host plant in relation to its susceptibility to attack by frugivorous Lonchaeidae.

The infestation index used was the number of pupae divided by the number of fruit and the number of pupae divided by the fruit's weight $(\mathrm{kg})$. The infestation frequency used was the number of infested fruit samples divided by the total of samples of each species multiplied by 100 and the number of flies of a species divided by the total number of flies multiplied by 100 (SOUZA FILHO et al., 2000; ARAÚJO et al., 2005).

A total of 2,966 fruits from 22 species and 14 botanical families were collected. Eighty-one flies from the genus Neosilba (Lonchaeidae) were collected in these fruits (33 females and 48 males). The Neosilba species collected were: $N$. inesperata Strikis \& Prado (2009), $N$. pendula Bezzi (1919) and N. zadolicha McAlpine (1982). These species are widely distributed in Brazil as they have been found in fruit in several Brazilian states (CAIRES et al., 2009; DIAS et al., 2012; LEMOS et al., 2015; RAGA et al., 2015; SOUZA et al., 2008; STRIKIS et al., 2011).

The highest frequencies of infestation by flies were in the Rutaceae (45\%), Anacardiaceae (19\%) and Myrtaceae (17\%) families, followed by Malpighiaceae (7\%), Rubiaceae (7\%) and Annonaceae (5\%). Although some species of Lonchaeidae are polyphagous (LEMOS et al., 2015; RAGA et al., 2015), these flies are ovipositors, and prefer to lay eggs in species of Rutaceae. The frequency of the Lonchaeidae infestation in some varieties of Citrus is higher than the Tephritidae species (RAGA et al., 2004; UCHÔA; NICÁCIO, 2010). The Neosilba species have predominance in oranges and tangerines than the other frugivorous flies (UCHÔA-FERNANDES et al., 2002).

Neosilba species were collected from 10 fruit species from seven botanical families in the Cerrado biome of Piauí. Neosilba flies were related to native fruit species and fruit species that were introduced to the Cerrado biome, infesting 22 of them (UCHÔA-FERNANDES et al., 2002); and in the Semi-Arid region, infesting eight of these species (ARAÚJO; ZUCCHI, 2002).

The low number of hosts found in the Semi-Arid region by these authors, and in the Cerrado biome of Piaui in the present work, is possibly due to the low availability of fleshy fruits, which are potential hosts of frugivorous flies (ARAÚJO; ZUCCHI, 2002).

Oranges had the largest number of adult Lonchaeidae (Table 1). Several fruit flies use oranges as hosts, such as the Anastrepha Schiner, Ceratitis capitata (Wiedemann, 1824) and Neosilba spp. (SOUZA et al., 2008). Moreover, N. zadolicha collected in orange samples was the only fruit fly considered a primary invader of oranges in the Cerrado biome of Piauí.

Neosilba zadolicha was the most common and polyphagous fly species. It was found in six species of five plant families. 
This fly species has the widest geographical distribution and host diversity in Brazil and is considered an important fruit pest grown in the Northeast and Southeast regions of the country (LOPES et al., 2007; RAGA et al., 2015).

However, $N$. inesperata and $N$. pendula did not show signs of polyphagia in the Cerrado biome, specifically in the state of Piauí. These species were considered polyphagous in the state of Sáo Paulo, with infestations of 37 (N. inesperata) and 21 (N. pendula) botanical species (RAGA et al., 2015). Moreover, $N$. pendula was considered an important primary invader of barbados cherry in the Semi-Arid region (ARAÚJO; ZUCCHI, 2002). Although the Semi-Arid region and the Cerrado biome in the state of Piauí present similar environmental conditions,
$N$. pendula was not considered a primary invader of the fruit species in Piauí.

Fly species of the Lonchaeidae family infests native fruit species and fruit species that were introduced to the Cerrado biome in the state of Piauí, especially typical fruit species that are commonly found in this region, such as those from the genus Spondias.

Orange is an economic important fruit and the most produced in Brazil. This fruit is not cultivated commercially in the southern Piauí. However, the occurrence of infestation by $N$. zadolicha, considered a primary invader of this fruit in this region, is an important factor for the commercial production of oranges.

Table 1. Lonchaeidae species and their host plants in the Cerrado biome in the state of Piauí, Brazil.

\begin{tabular}{|c|c|c|c|c|c|c|c|c|c|c|c|}
\hline \multirow[b]{2}{*}{ Plant Family } & \multirow[b]{2}{*}{ Plant Species } & \multirow[b]{2}{*}{ Origin } & \multirow{2}{*}{$\begin{array}{c}\text { Total } \\
\text { samples }\end{array}$} & \multicolumn{2}{|c|}{ Fruit } & \multicolumn{3}{|c|}{ Collected flies } & \multirow{2}{*}{$\begin{array}{c}\text { Neosilba } \\
\text { species } \\
\text { found }\end{array}$} & \multicolumn{2}{|c|}{ Infestation index } \\
\hline & & & & Number & $\begin{array}{l}\text { Weight } \\
\text { (kg) }\end{array}$ & Total & $\hat{0}$ & o & & $\begin{array}{l}\text { Pupae } \\
\text { per fruit }\end{array}$ & $\begin{array}{l}\text { Pupae } \\
\text { per kg }\end{array}$ \\
\hline \multirow{5}{*}{ Anacardiaceae } & Anacardium occidentale L. & $\mathrm{N}$ & 2 & 6 & 0.40 & - & - & - & - & - & - \\
\hline & Mangifera indica L. & 1 & 2 & 18 & 7.52 & 2 & 1 & 1 & N. zadolicha & 0.555 & 0.13 \\
\hline & Spondias dulcis Parkinson & 1 & 2 & 57 & 2.48 & 1 & 1 & - & N. inesperata & 0.010 & 0.40 \\
\hline & Spondias purpurea L. & 1 & 3 & 134 & 1.28 & 7 & 4 & 3 & N. pendula & 0.022 & 2.34 \\
\hline & Spondias tuberosa Arruda & $\mathrm{N}$ & 8 & 359 & 4.97 & 5 & 3 & 2 & N. zadolicha & 0.008 & 0.60 \\
\hline Annonaceae & Annona squamosa $\mathrm{L}$. & 1 & 5 & 26 & 4.05 & 5 & 2 & 3 & N. zadolicha & 0.077 & 0.49 \\
\hline Caricaceae & Carica papaya L. & 1 & 2 & 3 & 3.81 & - & - & - & - & - & - \\
\hline Cucurbitaceae & $\begin{array}{l}\text { Cucurbita moschata } \\
\text { (Dusc.) Poir }\end{array}$ & 1 & 3 & 6 & 6.56 & - & - & - & - & - & - \\
\hline Lythraceae & Punica granatum L. & 1 & 1 & 1 & 0.15 & - & - & - & - & - & - \\
\hline Malpighiaceae & $\begin{array}{l}\text { Malpighia emarginata } \\
\text { Sessé \& Moc. Ex DC }\end{array}$ & 1 & 9 & 955 & 6.02 & 3 & 3 & - & N. pendula & 0.003 & 0.49 \\
\hline \multirow{3}{*}{ Myrtaceae } & \multirow{2}{*}{ Psidium guajava L. } & \multirow{2}{*}{$\mathrm{N}$} & \multirow{2}{*}{12} & \multirow{2}{*}{415} & \multirow{2}{*}{18.59} & \multirow{2}{*}{12} & \multirow{2}{*}{7} & \multirow{2}{*}{5} & N. pendula & 0.002 & 0.05 \\
\hline & & & & & & & & & N. zadolicha & 0.014 & 0.32 \\
\hline & $\begin{array}{c}\text { Psidium cattleianum } \\
\text { Sabine }\end{array}$ & $\mathrm{N}$ & 5 & 747 & 6.07 & - & - & - & - & - & - \\
\hline Musaceae & Musa $\times$ paradisiaca $\mathrm{L}$. & 1 & 2 & 17 & 0.73 & 1 & - & 1 & Neosilba spp. & 0.060 & 1.36 \\
\hline Oxalidaceae & Averrhoa carambola L. & 1 & 2 & 64 & 1.84 & - & - & - & - & - & - \\
\hline Passifloraceae & Passiflora edulis Sims & $\mathrm{N}$ & 2 & 9 & 0.75 & - & - & - & - & - & - \\
\hline Rosaceae & Malus domestica Borkh & 1 & 2 & 5 & 0.65 & - & - & - & - & - & - \\
\hline \multirow{3}{*}{ Rubiaceae } & $\begin{array}{l}\text { Duroia valesca C. H. } \\
\text { Perss. \& Delprete }\end{array}$ & $\mathrm{N}$ & 1 & 30 & 1.05 & - & - & - & - & - & - \\
\hline & Genipa americana L. & $\mathrm{N}$ & 1 & 3 & 0.17 & 3 & 3 & - & N. zadolicha & 1.000 & 17.64 \\
\hline & Morinda citrifolia L. & 1 & 2 & 16 & 1.30 & - & - & - & - & - & - \\
\hline \multirow{2}{*}{ Rutaceae } & Citrus limonia Osbeck & 1 & 3 & 72 & 1.82 & - & - & - & - & - & - \\
\hline & Citrus sinensis (L.) Osbeck & 1 & 6 & 20 & 4.51 & 42 & 24 & 18 & N. zadolicha & 0.950 & 4.21 \\
\hline Solanaceae & Solanum lycopersicum L. & $\mathrm{N}$ & 1 & 3 & 0.14 & - & - & - & - & - & - \\
\hline Total & & & 76 & 2,966 & 73.02 & 81 & 48 & 33 & & & \\
\hline
\end{tabular}

$\mathrm{N}$ : native; I: introduced. 


\section{ACKNOWLEDGEMENTS}

The authors thank the professor Laura Jane Gisloti, of the Indigenous Intercultural Faculty (Universidade Federal da Grande Dourados, Mato Grosso do Sul, Brazil) for the identification of the insects of the family Lonchaeidae. To the teacher Dr. Adalton Raga (Instituto Biológico, São Paulo, Brazil) for the suggestions in scientific writing. The Universidade Estadual do Piauí, Campus Corrente (UESPI, Piauí, Brazil), for making available the Zoology Laboratory for field material screening.

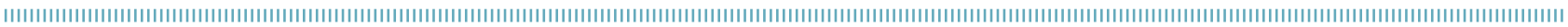
REFERENCES

ARAÚJO, E.L.; MEDEIROS, M.K.M.; SILVA, V.E.; ZUCCHI, R.A. Moscas-das-frutas (Diptera: Tephritidae) no semi-árido do Rio Grande do Norte: plantas hospedeiras e índice de infestação. Neotropical Entomology, Londrina, v.34, n.6, p.889-894, 2005. http://dx.doi.org/10.1590/S1519-566X2005000600003

ARAÚJO, E.L.; ZUCCHI, R.A. Hospedeiros e níveis de infestação de Neosilba pendula (Bezzi) (Diptera: Lonchaeidae) na região de Mossoró/Assú, Rio Grande do Norte. Arquivos do Instituto Biológico, São Paulo, v.69, n.2, p.91-94, 2002.

BOMFIM, D.A.; UCHÔA-FERNANDES, M.A.; BRAGANÇA, M.A.L. Biodiversidade de moscas-das-frutas (Diptera, Tephritoidea) em matas nativas e pomares domésticos de dois municípios do estado do Tocantins, Brasil. Revista Brasileira de Entomologia, Curitiba, v.51, n.2, p.217-223, 2007. http://dx.doi.org/10.1590/ S0085-56262007000200012

CAIRES, C.S.; UCHÔA-FERNANDES, M.A.; NICÁCIO, J.; STRIKIS, P.C. Frugivoria de larvas de Neosilba McAlpine (Diptera, Lonchaeidae) sobre Psittacanthus plagiophyllus Eichler (Santalales, Loranthaceae) no sudoeste de Mato Grosso do Sul, Brasil. Revista Brasileira de Entomologia, Curitiba, v.53, n.2, p.272-277, 2009. http://dx.doi. org/10.1590/S0085-56262009000200009

DIAS, N.S.; BROGLIO, S.M.F;; SANTOS, D.S.; SANTOS, J.M.; STRIKIS, P.C. First record of Neosilba (Diptera: Lonchaeidae) on Jatropha curcas L in Brazil. Arquivos do Instituto Biológico, São Paulo, v.79, n.3, p.423-424, 2012. http://dx.doi.org/10.1590/S1808-16572012000300015

EUROPEAN DISTRIBUTED INSTITUTE OF TAXONOMY (EDIT). Lonchaeidae online, number of species, 2013. Available from: <http://lonchaeidae.myspecies.info/>. Access on: Feb. 202018.

LEMOS, L.N.; ADAIME, R.; COSTA-NETO, S.V.; DEUS, E.G.; JESUSBARROS, C.R.; STRIKIS, P.C. New findings on Lonchaeidae (Diptera: Tephritoidea) in the Brazilian Amazon. Florida Entomologist, v.98, n.4, p.1227-1237, 2015. https://doi.org/10.1653/024.098.0433

LOPES, E.B.; BATISTA, J.L.; ALBUQUERQUE, I.C.; BRITO, C.H. Moscas frugívoras (Tephritidae e Lonchaeidae) ocorrência em pomares comerciais de tangerina na Paraíba. Tecnologia \& Ciência Agropecuária, João Pessoa, v.1, n.2, p.31-37, 2007.

MCALPINE, J.F. A new species of Dasiops (Diptera: Lonchaeidae) injurious to apricots. The Canadian Entomologist, v.93, n.7, p.539-544, 1961. https://doi.org/10.4039/Ent93539-7

RAGA, A.; MACHADO, R.A.; DINARDO, W.; STRIKIS, P.C. Eficácia de atrativos alimentares na captura de moscas-das-frutas em pomar de citros. Bragantia, Campinas, v.65, n.2, p.337-345, 2006.
RAGA, A.; PRESTES, D.A.O.; SOUZA FILHO, M.F.; SATO, M.E.; SILOTO, R.C.; GUIMARÃES, J.A.; ZUCCHI, R.A. Fruit fly (Diptera: Tephritoidea) Infestation in Citrus in the State of São Paulo, Brazil. Neotropical Entomology, Londrina, v.33, n.1, p.85-89, 2004. http://dx.doi.org/10.1590/ S1519-566X2004000100015

RAGA, A.; SOUZA FILHO, M.F.; ARTHUR, V.; MARTINS, A.L.M. Avaliação da infestação de moscas-das-frutas em variedades de café (Coffeaspp.). Arquivos do Instituto Biológico, São Paulo, v.63, n.2, p.59-63, 1996.

RAGA, A.; SOUZA FILHO, M.F.; STRIKIS, P.C.; MONTES, S.M.N.M. Lance fly (Diptera: Lonchaeidae) host plants in the State of São Paulo, Southeast Brazil. Entomotropica, Maracay, v.30, n.7, p.57-68, 2015.

RIQUELME, C.P.I.; HERNÁNDEZ, H.G.; CARRASCO, J.V.; CÁZARES, M.C.M.L.; MONTIEL, C.R. Lonchaeidae (Diptera: Tephritoidea) associated withthe genus Annona in Mexico. Southwestern Entomologist, v.40, n.1, p.121-130, 2015. https://doi. org/10.3958/059.040.0110

SILVA, R.A.; DEUS, E.G.; RAGA, A.; PEREIRA, J.D.B.; SOUZA FILHO, M.F.;COSTA-NETO, S.V. Monitoramento de moscas-das-frutas na Amazônia: amostragem de frutos e uso de armadilhas. In: SILVA, R.A.; LEMOS, W.P.; ZUCCHI, R.A. (Eds.). Moscas-das-frutas na Amazônia brasileira: diversidade, hospedeiros e inimigos naturais. Macapá: EMBRAPA, 2011 . p.33-50.

SOUZA, J.F.; SOUZA, S.A.S.; AGUIAR-MENEZES, E.L.; FERRARA, F.A.A.; NASCIMENTO, A.S.; RODRIGUES, W.C.; CASSINO, P.C.R. Diversidade de moscas-das-frutas em pomares de citros no município de Araruama, RJ. Ciência Rural, Santa Maria, v.38, n.2, p.518-521, 2008. http://dx.doi.org/10.1590/ so $103-84782008000200035$

SOUZA FILHO, M.F.; RAGA, A.; ZUCCHI, R.A. Incidencia de Anastrepha obliqua (Macquart) y Ceratitis capitata (Wiedemann) (Diptera: Tephritidae) en carambola (Averrhoa carambola L.) en ocho localidades del estado de São Paulo, Brasil. Anais da Sociedade Entomológica do Brasil, Londrina, v.29, n.2, p.367-371, 2000. http://dx.doi.org/10.1590/S0301-80592000000200020

SOUZA FILHO, M.F.; RAGA, A.; AZEVEDO-FILHO, J.A.; STRIKIS, P.C.; GUIMARÃES, J.A.; ZUCCHI, R.A. Diversity and seasonality of fruit flies (Diptera: Tephritidae and Lonchaeidae) and their parasitoids (Hymenoptera: Braconidae and Figitidae) in orchards of guava, loquat and peach. Brazilian Journal of Biology, São Carlos, v.69, n.1, p.31-40, 2009. http://dx.doi.org/10.1590/ S1519-69842009000100004 
STRIKIS, P.C.; DEUS, E.G.; SILVA, R.A.; PEREIRA, J.D.B.; JESUS, C.R.; MARSARO-JÚNIOR, A.L. Conhecimento sobre Lonchaeidae na Amazônia Brasileira. In: SILVA, R.A.; LEMOS, W.P.; ZUCCHI, R.A. (Eds.). Moscas-das-frutas na Amazônia brasileira: diversidade, hospedeiros e inimigos naturais. Macapá: EMBRAPA, 2011. p.205-215.

STRIKIS, P.C.; PRADO, A.P. A new species of the genus Neosilba (Diptera: Lonchaeidae). Zootaxa, v.828, n.1, p.1-4, 2005. http:// dx.doi.org/10.1 1646/zootaxa.828.1.1

UCHÔA, M.A.; NICÁCIO, J. New records of Neotropical fruit flies (Tephritidae), lance flies (Lonchaeidae) (Diptera: Tephritoidea), and their host plants in the south Pantanal and adjacent areas,
Brazil. Annals of the Entomological Society of America, v.103, n.5, p.723-733, 2010. https://doi.org/10.1603/AN09179

UCHÔA-FERNANDES, M.A.; OLIVEIRA, I.; MOLINA, R.M.S.; ZUCCHI, R.A. Populational fluctuation of frugivorous flies (Diptera: Tephritoidea) in two orange groves in the state of Mato Grosso do Sul, Brazil. Neotropical Entomology, Londrina, v.32, n. 1, p. 19-25, 2003. http://dx.doi.org/10.1590/S1519-566X2003000100003

UCHÔA-FERNANDES, M.A.; OLIVEIRA, I.; MOLINA, R.M.S.; ZUCCHI, R.A. Species diversity of frugivorous flies (Diptera: Tephritoidea) from hosts in the Cerrado of the state of Mato Grosso do Sul, Brazil. Neotropical Entomology, Londrina, v.31, n.4, p.515-524, 2002. http://dx.doi.org/10.1590/S1519-566X2002000400002 